\title{
単純クマリン類の感作性及び交差反応性
}

\author{
政本幸三 \\ 大阪成蹊女子短期大学家政学科
}

\section{Sensitization and Crossreaction of Simple Coumarins}

\author{
Yukimitsu MASAMOTO \\ Department of Home Economics, Osaka Seikei Women's College, 3-10-62, Aikawa, \\ Higashiyodogawa-ku, Osaka 533-0007, Japan
}

(Received September 6, 2000; Accepted October 27, 2000)

\begin{abstract}
The contact sensitization of 11 simple coumarins was examined by subcutaneous sensitizing of guinea pigs, and the structure-activity relationship and cross-reactivity were investigated. Esculetin, 4-methylesculetin, and daphnetin were found to be strong sensitizers, and 4-hydroxy-coumarin to be a moderate sensitizer. Other simple coumarins tested hed a weak sensitivity to mild sensitizers. The results suggest that the introduction of hydroxy group, especially adjacent substitution at the 6,7 , and 8 positions of the coumarin ring with two hydroxy groups, may play an important role in exhibiting the contact sensitization activity. The cross-reactivity was observed between esculetin and 4-methylesculetin, esculin or isoscoporetin, and also between daphnetin and 4-methylumbelliferone or umbelliferone, although there was no mutual cross-reactivity between esculetin and daphnetin. It is interesting to note that guinea pigs, which had a weak sensitivity to umbelliferone, showed a strong cross-reactivity to daphnetin, while those, which had a weak sensitivity to daphnetin, showed a weak cross-reactivity to umbelliferone. It is assumed that a skin-protein conjugation at 5 or 6 positions of the coumarin ring is important to elicit the cross-reactivity of esculetin or daphnetin groups.
\end{abstract}

Key words_— simple coumarins; contact sensitization; cross-reactivity; guinea pig; daphnetin; umbelliferone

\section{緒 言}

クマリン類は植物界に遊離あるいは配糖体として 広く分布し，特にセリ科，ミカン科などの樹皮， 葉，根に多く含まれている。今日では天然物また合 成物として 1,000 種類以上のクマリン化合物が見い 出されている.

クマリン類には光感作促進，抗炎症，種子発芽抑 制，冠状血管拡張，殺虫・抗菌作用などの生理・薬 理作用が報告されている. ${ }^{1-4)}$ なかでもソラレン, 8-メトキシソラレンなどのフロクマリン類の光毒性 作用については皮膚科領域で幅広く研究され， Psoralen Photochemotherapy (PUVA) 療法として 尋常性乾癬，尋常性白斑，円形脱毛症，アトピー性 皮膚炎など各種皮膚疾患の治療に用いられてい る. ${ }^{5-9)}$

一方，単純クマリン類は古くより香料やサンスク リーン剂として香粧品領域で応用され，光接触性皮 膚炎や接触性皮膚炎発生の報告も散見される。10-13) しかし，単純クマリン類を皮膚科領域に適用した場 合の安全性に関する研究報告は Kaidbey ${ }^{14,15)}$ Hausen ${ }^{16-18)}$ らの報告があるものの，系統的研究は 非常に少ない。著者は単純クマリン類を今後皮膚科 領域や香粧品領域に予防，治療の目的で利用するこ
とを考えるとき，クマリン類の主構造及び置換基の 種類と皮膚刺激性，接触感作性などの諸性質との関 係を正しく理解することが大切であると考え，本研 究を行った。本研究ではモルモットによる実験感作 を誘導し，単純クマリン類の1) 水酸基の結合数, 2) 水酸基の結合位置，3）蛋白結合性，4）皮内代 謝性につき比較検討し, 感作性あるいは交差感作性 の発現と構造との関係の解明を試みたので報告する.

\section{実 験 の 部}

\section{1. 実験材料}

使用した 11 種類の検体は Fig. 1 に示す構造式を 持つ一連の単純クマリン類である。 4-methylesculetin (4MET), esculetin (ET), 4-methylumbelliferone (4MU), 4-hydroxycoumarin (4HC), umbelliferone $(\mathrm{Um})$, coumarin $(\mathrm{Cm})$, esculin $(\mathrm{EL})$, daphnetin $(\mathrm{DH})$, 5,7-dihydroxy-4-methylcoumarin (57DH4MC), isoscopoletin (isoS), scoparone (SPA) はすべて Extrasynthese S. A. 社製の試薬を特に精製せずに用い た.

2. モルモット皮下投与法による感作性及び交差 感作性試験

感作性試験の方法は Fig. 2 に示す。ハートレー 系白色モルモット (雌性，6 週令) を各群 12 匹ずつ 
<smiles>O=c1ccc2ccccc2o1</smiles>

Coumarin $(\mathrm{Cm})$<smiles>O=c1cc(O)c2ccccc2o1</smiles><smiles>Cc1cc(=O)oc2cc(O)ccc12</smiles>

4-Hydroxycoumarin(4HC)

4-Methylumbelliferone(4MU)<smiles>O=c1ccc2ccc(O)cc2o1</smiles>

Umbelliferone (Um)<smiles>O=c1ccc2ccc(O)c(O)c2o1</smiles>

Daphnetin(DH)<smiles>O=c1ccc2cc(O)c(O)cc2o1</smiles>

Esculetin(ET)<smiles>Cc1cc(=O)oc2cc(O)c(O)cc12</smiles>

4-Methylesculetin(4MET)<smiles>O=c1ccc2cc(OC3CCCCC3)c(O)cc2o1</smiles>

Esculin(EL) (Glc= $\beta$-D-Gluco(pyrano)syl)<smiles>COc1cc2oc(=O)ccc2cc1O</smiles>

Isoscopoletin(isoS)

Fig. 1. Chemical Structures of Simple Coumarins Tested

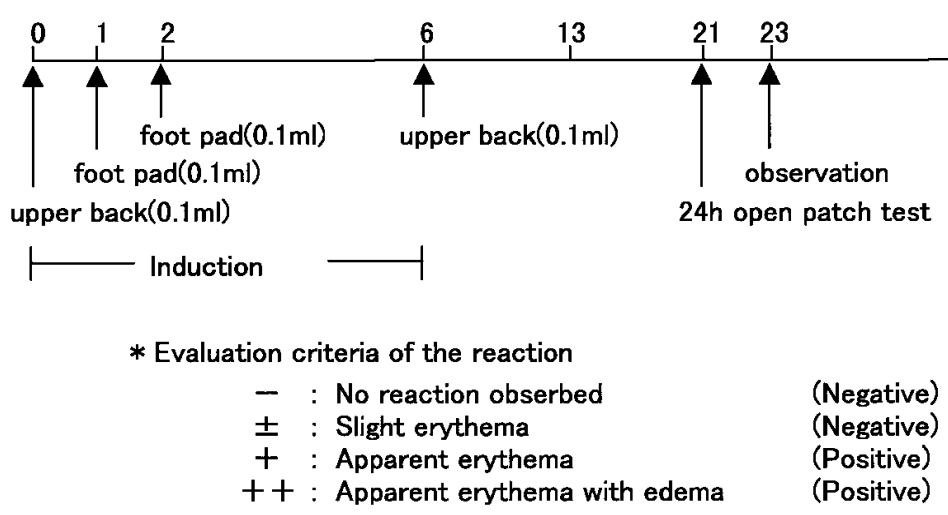

Fig. 2. Sensitization Schedule and Evaluation Criteria

を感作実験に供した。検体の $0.1 \mathrm{M}$ 含有 Freund's Complete Adjuvant (FCA) を乳鉢にて混合可溶化 したものを用い，モルモットの頸，足掌の皮下に 1 週間に 4 回，すなわち 1 日 1 回，1 力所，3 日連続 皮下注射 $(0.1 \mathrm{ml} \times 3)$ さらに 4 日後に再度頸部に 1 回の計 4 回の皮下注射を行った. 最初の感作日より 4 週間後, 検体の $10^{-1} \mathrm{M}$ と $10^{-2} \mathrm{M}$ 含有エタノール 溶液 $0.02 \mathrm{ml}$ の単純塗布惹起を行い, 48 時間後, Fig. 2 の判定基準に従って判定した. 感作性の強度 は Magnusson and Kligman ${ }^{19)}$ の方法に従って区分 した。

単純クマリン類間の交差感作性は上記単純塗布惹 起 7 日後, 各々 11 種のクマリン類を $10^{-1} \mathrm{M}$ 濃度 で，同操作により再惹起を行い，反応の有無を判定 した.

検体の皮膚一次刺激性評価は次のようにして行っ た。つまり検体を含まない FCA を同様の方法で感 作誘導した一群 10 匹のモルモットに検体の $10^{-1} \mathrm{M}$ と $10^{-2} \mathrm{M}$ 含有エタノール溶液を $0.02 \mathrm{ml}$ 単純塗布
し，48 時間後肉眼判定を行った。本濃度では何ら 刺激反応は認めなかった.

\section{3. 単純クマリン類の Human Serum Albumin} (HSA) への結合性実験

$1.1 \%$ HSA (Sigma 社製, Fraction V) 含有 $0.1 \mathrm{M}$ リン酸緩衝液 $(\mathrm{pH} 7.4) 9.9 \mathrm{ml}$ に検体の $1.5 \times 10^{-3} \mathrm{M}$ DMSO 溶液 $0.1 \mathrm{ml}$ を加えて最終濃度を $1.5 \times 10^{-4}$ $\mathrm{M}$ とし， $37^{\circ} \mathrm{C}$ で反応させた。 24 時間後， 2 倍量の メタノールを添加，よく混合し，2 時間冷所で放置 した。次に 3,000 r.p.m, 10 分間遠心後，得られた 上清液中の検体濃度 (A) は HPLC 法により測定し た。装置は島津 LC-3A と SPD-2A を用い，カラム は Nucleosil-10C $\mathrm{C}_{18}(4 \phi \times 250 \mathrm{~mm}$ Nagel), 移動相は メ夕ノール $-0.01 \mathrm{M} リ ン$ 酸緩衝液 $(\mathrm{pH} 2.5)(3: 7$ $\mathrm{V} / \mathrm{V})$, カラム温度は室温, 流速 $1.0 \mathrm{ml} / \mathrm{min}$, 検出 波長 $230 \mathrm{~nm}$ 又は $340 \mathrm{~nm}$, 注入量 $20 \mu \mathrm{l}$ で測定した。

一方 HSA 溶液を含まない $0.1 \mathrm{M} リ ン$ 酸緩衝液 （pH 7.4）を用い調製した検体溶液を同様に処理し て得られた上清液中の濃度 (B) を測定し，(B- 
$\mathrm{A} / \mathrm{B}) \times 100(\%)$ の式から蛋白結合率を計算した.

4. モルモット皮膚組織による代謝試験

1) 酵素溶液の調製 ハートレー系白色モルモ ット (雌, 6 週令) の腹側部の毛を刈り, 剃毛後断 頭・屠殺し，十分に放血させる。皮膚面は $70 \%$ ア ルコール溶液で洗浄後, 皮膚を剥離し, 皮下脂肪組 織を解剖用ハサミを用い，できるだけ取り除き，約 $0.5 \mathrm{~cm}$ 角に細切した。ついで皮膚重量の 2 倍量の 冷 $150 \mathrm{mM}$ 塩化カリウム溶液を加え, 水冷下でホモ ジナイズ後， 3,000 r.p.m, 10 分間遠心分離を行い, 得られた上清液を酵素液として使用した。酵素液は HSA を標品とし， Lowry 法により蛋白量を測定し た。えらばれた酵素溶液の蛋白量は $1.42 \mathrm{mg} / \mathrm{ml} て ゙$ あった。

2）基質溶液の調製 基質として esculin, umbelliferone, isoscopoletin を用い, すべて $1.5 \times 10^{-3}$ M DMSO 溶液とした。

3) In vitro 代謝実験代謝反応は基質溶液 $0.1 \mathrm{ml}$, 酵素溶液として皮膚抽出液 $0.2 \mathrm{ml}$ 及び 0.1 M クエン酸緩衝液 $\left(\mathrm{pH}\right.$ 5.5) $0.7 \mathrm{ml}$ を混合し, $37^{\circ} \mathrm{C}$, 18 時間反応させた. 反応後 $2 \%$ メタリン酸水溶液 9 $\mathrm{ml}$ を添加し，反応を停止させた。 2 時間放置後,

3,000 r.p.m, 10 分間冷却遠心し，得られた上清液を 上記 HPLC 分析条件で定性, 定量を行った。また 陽性対照として，アーモンド $\beta$-glucosidase（東洋紡 製 $11.1 \mathrm{units} / \mathrm{mg}$ ) 溶液, 陰性対照として, 加熱処 理 $\left(80^{\circ} \mathrm{C}, 10\right.$ 分間) 酵素溶液 $0.2 \mathrm{ml}$ を添加した反応 液について同様の操作で定性，定量を行つた。 反応 液から得られた各ピークの保持時間 (RT) と標準 物質の RT と一致した反応物について, それらの検 量線から生成量, 残存量 (未変化体) を算出した.

\section{結果}

\section{1. 単純クマリン類 11 種類の感作性試験}

単純クマリン類の $0.1 \mathrm{M}$ 濃度感作動物での開放塗 布惹起試験の結果を Table 1 に示した。1 $10^{-1} \mathrm{M}$ と
$10^{-2} \mathrm{M}$ 惹起濃度での感作率を平均し, Magnusson and Kligman の方法に従って感作性の強度を区分し た。4-Methylesculetin, esculetin 及び daphnetin は ランク IV (strong), 4-hydroxycoumarin はランク III (moderate), isoscopoletin と esculin はランク II (mild) となる. 5,7-dihydroxy-4-methylcoumarin, 4-methylumbelliferone, scoparone, coumarin そして umbelliferone の計 5 化合物はランク I (weak) となり，ほ とんど感作性を認めなかった.

\section{2. 単純クマリン類の HSA との結合性試験}

11 種の単純クマリン類の HSA との結合率を Table 2 に示した。 高い結合率を示したのは 2 個の水 酸基を両隣に持つ daphnetin と esculetin で, それ ぞれ 44.0\%, 42.4\%であった。ついで 4-methylesculetin が 27.4\% であった. 他のクマリン類の蛋白 結合率は 1 - $6 \%$ と軽度であった。

\section{3. 単純クマリン類の交差感作性試験}

単純クマリン類 11 種類による再惹起 48 時間後の 判定結果を Table 3 に示した。 交差感作反応は es-

Table 2. Binding Rate of Simple Coumarins on Human Serum Albumin

\begin{tabular}{lc}
\hline \hline \multicolumn{1}{c}{ Substance } & Binding rate (\%) \\
\hline 4-Methylumbelliferone & 6.5 \\
4-Methylesculetin & 27.4 \\
Esculetin & 42.4 \\
Umbelliferone & 2.0 \\
Coumarin & 1.8 \\
4-Hydroxycoumarin & 3.3 \\
Esculin & 5.2 \\
Daphnetin & 44.0 \\
Isoscopoletin & 1.3 \\
Scoparone & 3.1 \\
5,7-Dihydroxy-4-methylcomarin & - \\
\hline
\end{tabular}

- : not done

Table 1. Sensitizing Potencies of Simple Coumarins

\begin{tabular}{|c|c|c|c|c|}
\hline \multirow{2}{*}{ Substance } & \multicolumn{2}{|c|}{ Sensitization rate $(\%)$} & \multirow{2}{*}{ Grade } & \multirow{2}{*}{ Judgement } \\
\hline & $10^{-1} \mathrm{M}$ & $10^{-2} \mathrm{M}$ & & \\
\hline 4-Methylumbelliferone & 8 & 0 & I & Weak \\
\hline 4-Methylesculetin & 100 & 42 & IV & Strong \\
\hline Esculetin & 100 & 50 & IV & Strong \\
\hline Umbelliferone & 8 & 0 & I & Weak \\
\hline Coumarin & 0 & 0 & I & Weak \\
\hline 4-Hydroxycoumarin & 75 & 33 & III & Moderate \\
\hline Esculin & 25 & 0 & II & Mild \\
\hline Daphnetin & 100 & 50 & IV & Strong \\
\hline Isoscopoletin & 25 & 0 & II & Mild \\
\hline Scoparone & 0 & 0 & $\mathrm{I}$ & Weak \\
\hline 5,7-Dihydroxy-4-methylcoumarin & 0 & 0 & I & Weak \\
\hline
\end{tabular}


Table 3. Results of Cross-Challenge Test of Simple Coumarins

\begin{tabular}{lcrrrrrrrrrc}
\hline \multirow{2}{*}{ Crossreaction rate (\%) } & \multicolumn{10}{c}{ Challenge chemicals } \\
\cline { 2 - 11 } Sensitizer & 4MU & 4MET & ET & Um & Cm & 4HC & EL & DH & isoS & SPA & 57DH4MC \\
\hline 4-Methylumbelliferone (4MU) & 8 & 0 & 0 & 0 & 0 & 0 & 0 & 25 & 0 & 0 & 0 \\
4-Methylesculetin (4MET) & 0 & 100 & 100 & 0 & 0 & 0 & 33 & 0 & 0 & 0 & 0 \\
Esculetin (ET) & 0 & 67 & 100 & 0 & 0 & 0 & 50 & 0 & 33 & 0 & 0 \\
Umbelliferone (Um) & 8 & 0 & 0 & 8 & 0 & 0 & 0 & 100 & 0 & 0 & 0 \\
Coumarin (Cm) & 0 & 0 & 0 & 0 & 0 & 0 & 0 & 0 & 0 & 0 & 0 \\
4-Hydroxycoumarin (4HC) & 0 & 0 & 0 & 0 & 0 & 75 & 0 & 0 & 0 & 0 & 0 \\
Esculin (EL) & 0 & 0 & 50 & 0 & 0 & 0 & 25 & 0 & 0 & 0 & 0 \\
Daphnetin (DH) & 8 & 0 & 0 & 17 & 0 & 0 & 0 & 100 & 0 & 0 & 0 \\
Isoscopoletin (isoS) & 0 & 0 & 42 & 0 & 0 & 0 & 0 & 0 & 25 & 0 & 0 \\
Scoparone (SPA) & 0 & 0 & 0 & 0 & 0 & 0 & 0 & 0 & 0 & 0 & 0 \\
5,7-Dihydroxy-4-methylcoumarin (57DH4MC) & 0 & 0 & 0 & 0 & 0 & 0 & 0 & 0 & 0 & 0 & 0 \\
\hline
\end{tabular}

Table 4. Metabolites of Esculin, Isoscopoletin and Umbelliferone by Homogenized Guinea Pig Skin Extracts, and Enzymatic Hydrolysis of Esculin by $\beta$-Glucosidase

\begin{tabular}{|c|c|c|c|}
\hline Substrate & Enzyme source & Detected substance & Concentration (M) \\
\hline \multirow{5}{*}{ Esculin } & \multirow{2}{*}{ Skin extract $\left.{ }^{1}\right)$} & Esculin & $0.77 \times 10^{-4}$ \\
\hline & & Esculetin & $0.64 \times 10^{-4}$ \\
\hline & \multirow{2}{*}{$\beta$-Glucosidase ${ }^{2)}$} & Esculin & $0.99 \times 10^{-4}$ \\
\hline & & Esculetin & $0.53 \times 10^{-4}$ \\
\hline & Heat-treated skin extract ${ }^{1)}$ & Esculin & $1.49 \times 10^{-4}$ \\
\hline \multirow{2}{*}{ Isoscopoletin } & Skin extract ${ }^{1)}$ & Isoscopoletin & $1.40 \times 10^{-4}$ \\
\hline & Heat-treated skin extract ${ }^{1)}$ & Isoscopoletin & $1.45 \times 10^{-4}$ \\
\hline \multirow{2}{*}{ Umbelliferone } & Skin extract ${ }^{1)}$ & Umbelliferone & $1.30 \times 10^{-4}$ \\
\hline & Heat-treated skin extract ${ }^{1)}$ & Umbelliferone & $1.45 \times 10^{-4}$ \\
\hline
\end{tabular}

1) Protein concentration: $28.4 \mu \mathrm{g} / \mathrm{ml}, 2)$ Almond $\beta$-D-Glucosidase: $5.6 \times 10^{-1} \mu \mathrm{g} / \mathrm{ml}(11.1 \mathrm{units} / \mathrm{mg})$

culetin と 4-methylesculetin, esculinあるいはisoscopoletin 間, daphnetin と umbelliferone あるいは 4-methylumbelliferone 間に認められた。4-hydroxycoumarin, scoparone, 5,7-dihydroxy-4-methylcoumarin は他の単純クマリン類と何ら交差反応性を示さなか った.

\section{Esculin, umbelliferone, isoscopoletin $の$ in vitro 皮内代謝実験}

11 種類の単純クマリン類の中で，それ自身の感 作性は弱いが，他の単純クマリン類と高い交差反応 性を示した umbelliferone, esculin, isoscopoletin 取り上げ，モルモット皮膚組織抽出物を酵素液とし た代謝実験を行った。その結果を Table 4 に示した. 3 種クマリン類の中で明確に代謝物が検出されたの は esculin のみである。 その代謝物は HPLC 分析で 標品との比較より esculetin であると同定された. さらに， $\beta$-glucosidase の作用により esuclin から esculetin が簡単に生成されることも確認した (Table
4 及び Fig. 3)。一方，isoscopoletin, umbelliferone の反応溶液からは何ら新しい代謝物は検出されなか つた.

\section{考察}

化学物質の構造と皮膚反応性との間にある種の相 関性が存在することは知られている。 Takase と Konishi20) はキサンテン系色素の中で光毒性を発現 する化合物は構造中にいくつかのハロゲン分子を持 つこと, 皮膚構成成分と安定結合し，皮内残留性の 高いことなどの特徴を指摘している．著者21-24)ら はフェノール性水酸基に対しオルト，パラ位に水酸 基を持つ 2 価， 3 価フェノールの感作性は高く，か つ水酸基の増加につれ増大すること，また皮膚刺激 性と接触感作性の発現には置換基 (水酸基, アミ) 基など) の種類や置換基の相対的結合位置 (オル ト、メタ,パラなど) が重要な役割を果たしている ことを明らかにした。 


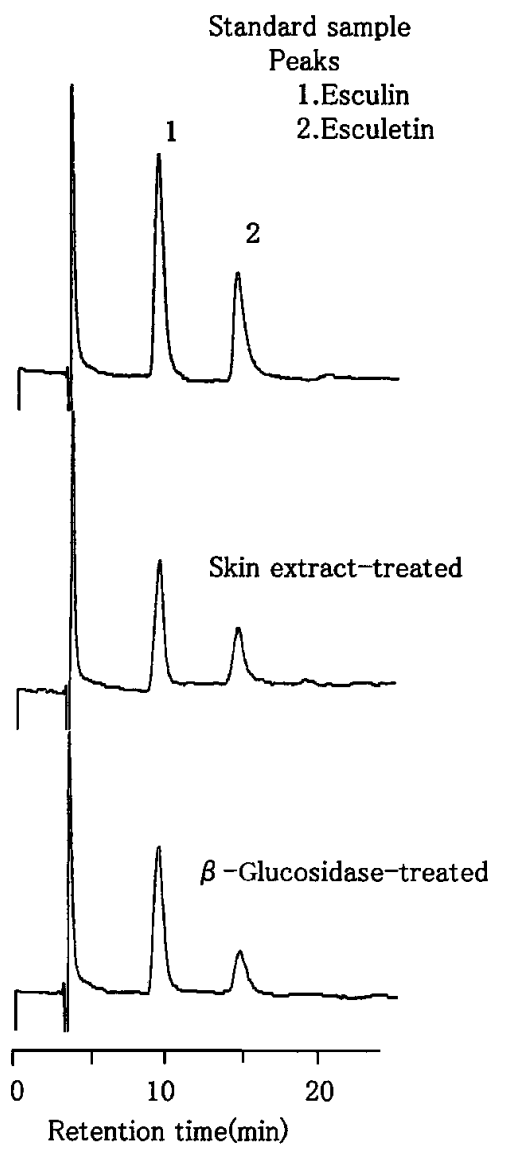

Fig. 3. HPLC Patterns of the Hydrolytic Products Obtained from Esculin Treated with Guinea Pig Skin Extract or $\beta$ Glucosidase

The retention times of esculin and esculetin are about 9.4, $14.5 \mathrm{~min}$, respectively.

今回著者が取り上げた単純クマリン類の皮膚安全 性に関する研究は少ない. Hausen 16-18)らは単純ク マリン類の化学構造と接触感作性について検討し,

5 と 7 位あるいは 6 と 7 位に水酸基を持つ esculetin, 4-methylesculetin, 5,7-dihydroxycoumarin に 感 作性が認められること，4位が methyl 化されると 感作性は低下することを報告している．著者は本論 文において 11 種類の単純クマリン類について別の 感作誘導法を用い，感作性の強さを分類した。 その 結果，基本構造である coumarin には感作性は認め られないが，4-hydroxycoumarin, umbelliferone と 4-methylumbelliferone との比較より, 感作性の発 現には 4-methyl 基の寄与はないが，4-OH 基は強く 寄与している。次に芳香環上の 7 位に水酸基を持つ umbelliferone では弱いながらも感作性が認められ た。さらに隣接位に 2 個の水酸基を持つ esculetin と daphnetin では強い感作性を示した。しかし，互 いにメ夕位の関係にある位置に 2 個の水酸基を持つ 5,7-dihydroxy-4-methylcoumarin には感作性を認め なかつた。 また 2 個の水酸基の 1 個が methy 化あ るいは glucosyl 化された isoscopoletin, esculin では
感作性は大幅に減弱し，さらに 2 個の水酸基すべて が methyl 化された scoparone では感作性は消失す ることを見出した．以上の結果より単純クマリン類 の感作性には 1 個の水酸基が 4 位に結合するか, 芳 香環上の隣接位に 2 個の水酸基が結合することの重 要が示唆された。本研究の結果は Hausen らのそれ とは必ずしも一致しないが，この差異は感作誘導や 誘導の条件の違いなどによるものと思われる，著者 の採用した感作誘導法は単純クマリン類の接触感作 性を感度よく検出できる優れた方法であると考えら れた。

さて，低分子化合物が抗原性を発揮するために は, 多くの場合蛋白質と結合して完全抗原になる必 要がある。単純クマリン類が接触皮膚炎を発現する ためには恐らく表皮内成分と結合するのであろう. 今回, 強い感作性を認めた 4-methylesculetin, esculetin, daphnetin が in vitro 系において Human serum albumin と高い結合性を示したことは感作性発 現に皮膚成分, 特に蛋白質との結合の重要性が示唆 された (Table 2). しかし，中等度の感作性を示し た 4-hydroxycoumarin や esculin などでは明確な蛋 白結合性が認められなかった。これらのクマリン類 は多分皮内で代謝を受けて生成される化合物が皮膚 蛋白と結合し，感作性を発現するものと考えられる。

次に，単純クマリン類の交差感作反応について, 著者の実験結果を Fig. 4 にまとめた。交差反応を 示した単純クマリン類は大きく 2 つのグループに分 類できる.つまり, esculetin を中心にしたグループ と daphnetin を中心にしたグループに区別される. 交差反応の発現にはそのままか，あるいは皮内で代 謝を受け，両物質が極めて類似した抗原決定構造を 示すようになる必要がある。したがって esculetin と daphnetin グループ間の交差反応不成立は皮内で 生成される抗原決定構造が各々異なることを示唆し ている. Esculetin 群の中で，先ず 4-methylesculetin と esculetinの交差反応性は両物質の構造上の類 似，特に芳香環の置換基及び置換様式の同一性によ るものと判断できる。 また, esculetin と esculin あ るいは isoscopoletin との交差反応については皮内 代謝により生成された esculetin が中心的役割を果 たしていると考えられる. Esculinについては in vitro 皮内反応結果が示す通り，皮内において酵素 $\beta$-glucosidase の作用により esculetin が生成され る。一方，今回の実験結果からは確認できなかった が，isoscoporetinの場合は，多分皮内に存在する methyltransferaseにより，脱 methyl 化を受け esculetin が生成されている可能性が高いと思われる. Methyltransferase は皮内に存在すること, ${ }^{25,26)}$ また Furuya, ${ }^{27)}$ Braymer, Shetlar et. al ${ }^{28)}$ ら scoparone と scopoletin をウサギとラットに経口投与し，その代 謝物を調べた結果, 脱 methyl 化を受けた scopoletin, isoscopoletin そして esculetin が生成されるこ 


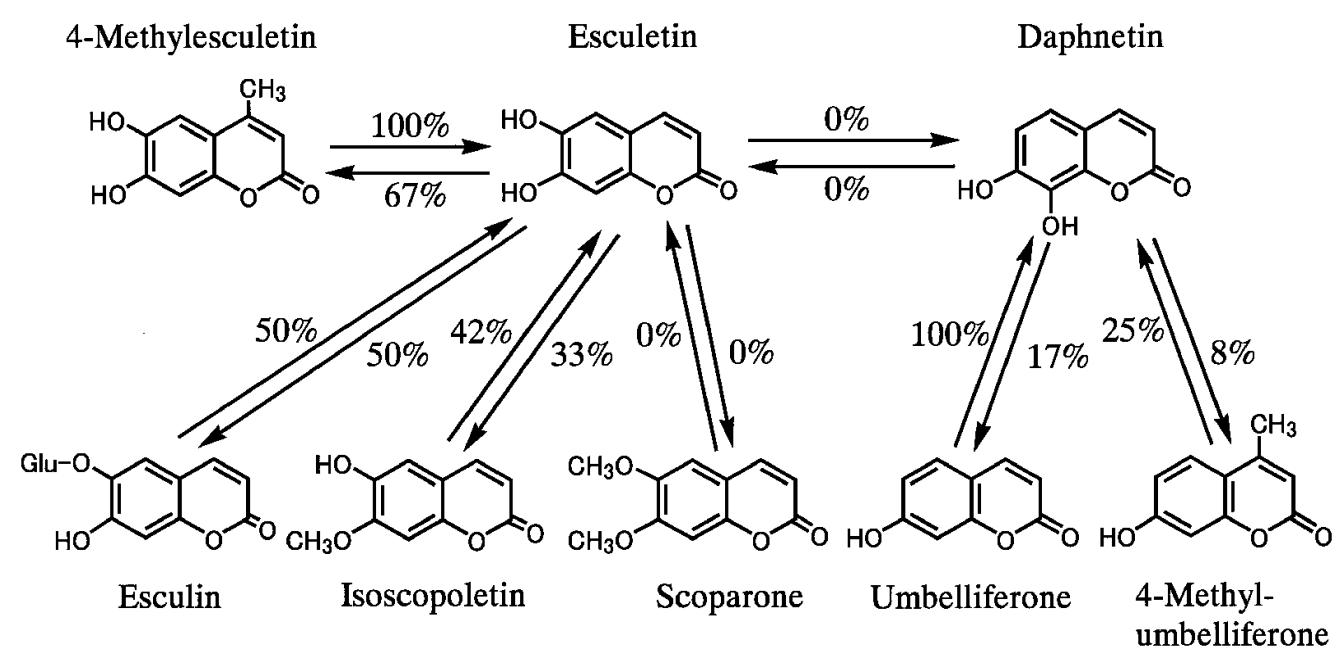

Fig. 4. Cross-Sensitivity Reactions in Daphnetin and Esculetin Groups

と，またその際，脱 methyl 化反応は 6 位に起こり やすいこと29)などの報告があり，著者の仮説を支持 している。このことは esculetin と esculin, isoscopoletin あるいは scoparone との交差反応性の強弱 は皮内代謝による esculetin 生成量が密接に関係し ていることを示している.

一方, daphnetin と umbelliferone 類との交差反 応において, umbelliferone 単独の感作性は低いが, daphnetin と高い交差反応性を示すという興味ある

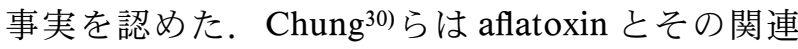
化合物の感作実験で同様の所見を報告している.

Umbelliferone がこの反応を発現するためには皮内 代謝を受け daphnetin と極めて類似した抗原決定構 造の形成が必要である。しかし，今回の代謝実験か らは何ら新しい生成物の検出はなく, 交差反応性を 証明する事実は見出せなかった。

Barratt ${ }^{31}$ ら $は$ phenol 系化合物の一般的な付加反 応メカニズムとして (1) poison ivy メカニズム, (2) phenol 性メカニズム, (3)ベンゼン性メカニズムの3 つの反応ルートの存在を報告している. Phenol 系 化合物とよく似た構造を持つ単純クマリン類につい て Barratt の理論を適用し, その感作と交差感作义 カニズムについて考察を加えた．先ず隣接位に 2 個 の水酸基を持つ daphnetin と esculetin は皮内で orthoquinone が生成され，電子配向性より 5 位， 6 位 あるいは 8 位で蛋白質と結合し，感作性を発現して いると考えるのが一般的であろう. Esculetin の場 合，蛋白結合部位としてクマリン核の 5 位あるいは 8 位が考えられるが, esculetin と 4-methylesculetin の感作性，交差感作性には大きな差が認められない ことから，5位での蛋白結合の可能性が考えられ る。一方, daphnetinの場合 5 位あるいは 6 位との 結合が考えられるが, daphnetinの6 位が methoxy 化された fraxetin では感作性が認められないこと ${ }^{17)}$ より，6位での蛋白との結合が感作性の発現にはよ
り重要であると考えられる。また 6 位に結合してい るからこそ umbelliferone と交差反応が認められた とも考えられる．今まで著者が述べてきた esculetin と daphnetin を中心にした感作や交差反応メカニズ ムに関する仮説は, 今後研究を進め, 検証していき たい.

今回著者は 11 種類の単純クマリン類の感作性及 び交差感作性について解析を行った。その結果，感 作性の発現にはクマリン核への水酸基の結合が必要 である．特に芳香環上の隣接位に 2 個の水酸基が結 合すると強い感作性を示すこと, 水酸基をアルキル 基で修飾することで感作性が減弱することを示し た．また交差感作性について，単独では弱い感作性 を示す単純クマリン類が, 強い感作性を示す単純ク マリン類と高い交差反応性を示すことが明らかとな った。このことは既に生活環境中に存在する類似物 質との交差反応性チェックの必要性や皮内代謝研究 の重要性が示唆された。今後, 種々の生理, 薬理作 用を持つ単純クマリン類を香粧品領域や皮膚科領域 に予防あるいは治療の目的に応用を考えるとき，こ れら一連の化学物質の構造と皮膚安全性との間に存 在する構造活性相関を明らかにすることはより安全 性の高い化粧品, 医薬品の原料や薬剤開発に貢献で きるものと思われる.

\section{REFERENCES}

1) Sione O. S., J. Pharmaceutic. Sci., 53, 231-264 (1964).

2) Ozeki Y., Ito T., Nakaya S., Folia Fharmacol. Jpn., 69, 869-880 (1973).

3) Ito T., Abstract of the 9th Annual Meeting of Medical and Pharmaceutical Society of Wakan-Yaku, 1975, pp. 43-50.

4) Murray R. D., Mendez J., Bron S. A., "The natural coumarins," Chrochester, John Wiley 
\& Son, 1982, pp. 1-455.

5) Weissmann I., Hofmann A. J., Wogner G., Arch Dermatol Res., 262, 333-336 (1978).

6) Morison W. J., Parrish J. A., Fitzpatrik T. B., Br. J. Dermatol., 98, 25-30 (1978).

7) Heidbreder G., Christophers E., Arch Dermatol. Res., 264, 331-337 (1979).

8) Anderson T. F., Voorhees J. J., Ann. Rev. Pharmacol. Toxicol., 20, 235-257 (1980).

9) Yamashita S., Miura Y., Ueki K., Tuboi R., Takamori K., Ogawa H., Jap. J. Dermatol., 109, 1471-1477 (1997).

10) Malton K. E., Acta Dermato-venereologica., 85, 117-121 (1979).

11) Comaish J. J., Kersey P. J., Contact Dermatitis, 6, 150-151 (1980).

12) Malton K. E., van Ketel W. G., Nater J. P., Liem O. H., Contact Dermatitis, 15, 289-294 (1986).

13) Hausen B. M., Rothenborg H. W., Arch. Dermatol., 117, 732-734 (1981).

14) Kaidbey K. H., Kligman A. M., Contact Dermatitis, 4, 277-282 (1978).

15) Kaidbey K. H., Kligman A. M., Arch. Dermatol., 117, 258-263 (1981).

16) Hausen B. M., Schmieder M., Contact Dermatitis, 15, 157-163 (1986).

17) Hausen B. M., Kallweit M., Contact Dermatitis, 15, 289-294 (1986).

18) Hausen B. M., Berger M., Contact Dermatitis, 21, 141-147 (1989).

19) Magnusson B., Kligman A. M., J. Inv. Derm.,
52, 268-276 (1969).

20) Takase Y., Konish H., "Sunlight and Man," ed. by Fitzpatrik B. T., Normal and Abnormal Photobiologic Responses, University of Tokyo Press, Tokyo, 1972, pp. 445-457.

21) Masamoto Y., Takase Y., Shinshu Med., 28, 367-374 (1980).

22) Masamoto Y., Takase Y., Shinshu Med., 31, 522-528 (1983).

23) Tsuyosh T., Masamoto Y., J. Soc. Cosmet. Chem. Japan, 18, 106-111 (1984).

24) Masamoto Y., Takase Y., Shinshu Med., 35, 185-193 (1987).

25) Kao J., Carver M. P., "Drug and Metabolism," Mancel Dekker, 1990 pp. 213218.

26) Thompson D. C., Constantini-Thocdosin D., Molders P., Chem. Biol. Interactions, 77, 137-147 (1991).

27) Furuya J., Chem. Pharm. Bull., 6, 696-701 (1958).

28) Braymer H. D., Shetlor M. R., Wender S. H., Biochim. Biophys. Acta, 44, 606-610 (1960).

29) Chihara G., Kurosawa N., Mizushima A., Matsuo K., Yoshioka Y., Arimoto K., Sugano S., Intern. Symp. Mol. Struct. Spectry., Tokyo, C117 (1962); Idem, Chem. Abstr., 61, 4805 (1964).

30) Chung C. W., Giles A. C, Carson J. R., J. Invest. Dermatol., 55, 396-403 (1970).

31) Barratt D. M., Basketter A. D., Contact Dermatitis, 27, 98-104 (1992). 